\title{
ANDRZEJ DĄBROWSKI
}

\section{CZY EMOCJE MOGĄ BYĆ RACJONALNE? ANALIZA WYBRANYCH ASPEKTÓW FILOZOFII EMOCJI RONALDA DE SOUSY}

Słowa kluczowe: emocje, obiektywność emocji, prawdziwość emocji, racjonalność, racjonalność emocji, racjonalność aksjologiczna

Keywords: emotions, objectivity of emotions, truth of emotions, rationality, rationality of emotions, axiological rationality

W środowisku filozoficznym Ronald de Sousa uchodzi za jednego z najwybitniejszych znawców problematyki emocji, czego dowodem może być zaproszenie go do zredagowania hasła „Emotion” w Stanford Encyclopedia of Philosophy. Należy on do grupy współczesnych filozofów, którzy uważają, że emocje w jakiejś mierze są racjonalne. Niniejszy artykuł jest próbą zrekonstruowania i oceny najważniejszych elementów filozofii emocji de Sousy, zwłaszcza jego koncepcji racjonalności emocji. W tym celu skorzystam przede wszystkim z The Rationality of Emotion. Częściowo odniosę się

* Andrzej Dąbrowski - doktor filozofii, adiunkt Zakładu Kognitywistyki w Wyższej Szkole Informatyki i Zarządzania w Rzeszowie. Główne obszary zainteresowań: kognitywistyka, epistemologia, filozofia umysłu, filozofia języka oraz historia filozofii analitycznej. Autor książki Intencjonalność i semantyka (Kraków 2013).

Address for correspondence: Andrzej Dąbrowski, Zakład Kognitywistyki, Wyższa Szkoła Informatyki i Zarządzania, ul. Sucharskiego 2, 35-225 Rzeszów. E-mail: adabrowski@wsiz.rzeszow.pl. 
też do późniejszych prac filozofa, w których rozwija on zagadnienia zasygnalizowane tylko lub szczątkowo omówione w The Rationality of Emotion ${ }^{1}$. Odniosę się tylko częściowo, ponieważ wraz z książką Emotional Truth filozofia emocji de Sousy ulega pewnej transformacji. Do głosu dochodzi w niej np. pytanie egzystencjalne: Jak żyć, żeby nasze życie było mniej nudne i zarazem bardziej szczęśliwe? Ani genezą tej ewolucji (przeobrażenia), ani późniejszymi poglądami nie będę się tutaj zajmował. Zupełnie pominę też rozważania de Sousy na temat emocjonalności w kontekście moralności.

Często emocje traktuje się jako: (1) stany czysto subiektywne, ściśle powiązane z prywatnym doświadczeniem podmiotu; (2) zjawiska zakłócające lub zniekształcające poznanie rzeczywistości, oddalające podmiot od prawdy; (3) zjawiska irracjonalne. De Sousa nie przeczy temu, że czasami pewne emocje mogą jawić się właśnie w ten sposób. Jego zdaniem można jednak argumentować za następującymi tezami (które tworzą przeciwwagę dla (1), (2) i (3)):

(T1) Emocje mają obiektywne własności.

(T2) Emocjom można przypisać prawdziwość.

(T3) Emocje wykazują cechy racjonalności, a nawet więcej: są racjonalne wedle własnych standardów.

Czy o emocjach, które uchodzą za zjawiska subiektywne, można mówić, że dostarczają nam obiektywnej wiedzy o świecie i są poprawne lub prawdziwe? Subiektywiści udzielali negatywnej odpowiedzi, twierdząc, że własności ujmowane przez emocjonalny podmiot są jedynie podmiotowymi projekcjami rzeczywistości. Inaczej obiektywiści, z którymi sympatyzuje de Sousa. Ich zdaniem emocje ujmują przedmioty i zdarzenia takimi, jakimi one są, i dostarczają nam prawdy o świecie.

Natomiast problem racjonalności ma tutaj dwa aspekty. Pierwszy dotyczy roli, jaką emocje odgrywają w tradycyjnie pojmowanych zdolnościach racjonalnego myślenia i działania: w nabywaniu przekonań i pragnień,

Szczegółową analizę i krytykę poglądów de Sousy przeprowadziła Joanna Krzemkowska-Saja w swojej rozprawie doktorskiej (Krzemkowska-Saja, 2014). Rozważania autorki koncentrują się głównie na trzech zagadnieniach: obiektywności, prawdziwości i racjonalności emocji. Warto podkreślić, że poglądy de Sousy stanowią jedynie punkt wyjściowy (lub odniesienia) w refleksji autorki na te tematy. Krzemkowska-Saja korzysta również z pewnych ustaleń i dorobku innych badaczy zajmujących się problematyką emocji (m.in. takich jak: A. Ben-Ze'ev, S. Döring, C.Z. Elgin, P. Goldie, B.W. Helm, R.C. Roberts i M. Salmela). 
przechodzeniu jednych przekonań $\mathrm{w}$ inne oraz ich przemianie w różne strategie działania. Drugi aspekt dotyczy emocji jako nieodłącznego elementu doświadczenia i życia podmiotu. Tutaj filozof pyta wprost: czy emocje same w sobie podlegają racjonalnej ocenie? Jeżeli tak, to $\mathrm{w}$ jakim sensie i do jakiego stopnia?

Z tą ogólną tezą ściśle wiąże się inna, bardziej szczegółowa, mniej kontrowersyjna niż poprzednie, ale wciąż różnie interpretowana teza, a mianowicie:

(T3’) Emocje są intencjonalne.

Dalsze rozważania stanowią próbę objaśnienia treści powyższych tez (niekoniecznie w podanej tutaj kolejności).

Rozpocznę od kilku ogólnych uwag na temat tego, jak de Sousa pojmuje emocje.

\section{Czym są emocje?}

Na pytanie, czym są emocje, de Sousa nie odpowiada wprost. Filozof pisze: „Przyznaję, że nie jestem w stanie podać definicji emocji” (de Sousa, 1987, s. 19). W jakimś stopniu przyjmuje on negatywną strategię i raczej pokazuje, czym emocje nie są, a nie, czym są.

W swoich poszukiwaniach genezy i prawdziwej natury emocji de Sousa pochyla się nad dorobkiem innych, analizuje i ocenia wybrane, istniejące już rozwiązania. Przede wszystkim pyta o poznawcze teorie emocji, zwłaszcza te, w których emocje analizowane są w kontekście takich stanów mentalnych, jak percepcje, przekonania, pragnienia. Jak wiadomo pojęcia te - zwłaszcza pojęcia ,przekonania” i ,pragnienia” - odgrywają kluczową rolę w wyjaśnieniu zachowania i są zasadniczymi elementami znanych teorii racjonalności. Niektórzy uważają nawet, że do wyjaśnienia ludzkich doświadczeń i zachowań niczego oprócz tych stanów nie potrzeba. Wypełniają one bowiem naszą przestrzeń pojęciową, a to, co nazywamy emocjami, jest jedynie pewną kombinacją tych stanów-elementów².

2 W tym duchu przedstawiali swoje poglądy na emocje m.in. John R. Searle (1983, 1992) i Joel Marks (1982). Ten ostatni przyjął następujące dwa założenia: (1) emocje są zjawiskami psychicznymi; (2) wszystkie zjawiska umysłowe można podzielić na trzy części: odczucia, przekonania i pragnienia. Marks zakłada więc, że emocje nie tworzą własnego rodzaju i muszą być analizowane pod kątem odczuć, przekonań, i/lub pragnień. 
Niestety, wbrew tym, którzy tak myślą, emocje nie dają się zredukować do przekonań i pragnień. Nie jest to możliwe, ponieważ - ograniczając się do przekonań: (1) można żywić pewne emocje, nie bacząc na to, do czego jesteśmy przekonani, można bać się czegoś i równocześnie być przekonanym, że nic nam nie zagraża (np. oglądając straszną scenę w kinie) oraz dlatego, że (2) formalne przedmioty emocji mogą być bardzo różne (de Sousa, 1987, s. 165). Przeciwko utożsamieniu emocji z przekonaniem w jakiejś mierze przemawia też antynomia integralności.

De Sousa sprawdza też, na ile zadowalające są wyjaśnienia biologiczne. Najpierw pyta o to, w jaki sposób myślenie o emocjach w kategoriach fizjologicznych może polepszyć zrozumienie ich natury, by następnie przejść do ewolucyjnej perspektywy. Pierwszym i największym zwolennikiem definiowania emocji w kategoriach fizjologii był William James. Jego zdaniem, tradycyjny pogląd - że stany mentalne (emocjonalne) wywołują zmiany cielesne - jest fałszywy. James utrzymuje, ,że zmiany cielesne są bezpośrednim następstwem faktu wywołującego pobudzenie i że odczuwanie przez nas samych tych zmian w trakcie ich pojawiania się jest emocją" (James, 2002, s. 345).

Zastrzeżenia de Sousy wobec rozwiązania Jamesa są trojakiego rodzaju: (1) nie istnieje percepcja trzewiowa; (2) leżące u podstaw emocji fenomeny fizjologiczne mają charakter tylko ogólnego pobudzenia; (3) istnieją emocjonalne obwody zlokalizowane w systemie limbicznym mózgu (de Sousa, 1987, s. 47).

Wedle de Sousy w ramach biologii możemy wyróżnić dwa sposoby wyjaśnień - bliższe i dalsze. Biologia ewolucyjna dostarcza „dalszego” -w odróżnieniu od „najbliższego”, fizjologicznego - poziomu wyjaśnienia. Biologiczne korzenie emocji stanowią ważny moment $\mathrm{w}$ określaniu ich funkcji, natomiast niewiele mówią na temat ich potencjalnej racjonalności i obiektywności. Wedle de Sousy dalekiemu i bliższemu poziomowi wyjaśniania odpowiadają dwa rodzaje teleologii: adaptacyjna i intencjonalna. Na pierwszą wskazuje fakt, że organy i mechanizmy behawioralne są dostosowane do środowiska. Prototypem drugiej jest rozmyślne działanie.

Następnie Marks argumentuje, że emocje nie są tylko odczuciami, ponieważ emocje są intencjonalne, a odczucia nie są intencjonalne; emocje nie są też tylko rodzajem przekonań, bo same przekonania nie są wystarczające do tego, aby spowodować zjawiska emocjonalne - potrzebne są również pragnienia. Jego zdaniem emocje to ,pprzekonania-plus-silne pragnienia” (por. Marks, 1982, s. 227, 233). 
W tym kontekście pojawia się pojęcie intencjonalności, które jest rozumiane przez de Sousę dosyć szeroko (więcej o tym w dalszej części artykułu) ${ }^{3}$. Do problemu racjonalności emocji w perspektywie biologicznej filozof powróci w późniejszych publikacjach (przede wszystkim w: de Sousa, 2008).

Czym zatem są emocje wedle de Sousy? W jego rozumieniu emocje są rodzajem poznania, a dokładniej - są bezpośrednim ujęciem (percepcją) jakości aksjologicznych: „emocje najlepiej uważać za rodzaj percepcji, przedmiotem których są, jak to nazywam, własności aksjologiczne" (de Sousa, 1987, s. 45). Jakościami tymi są m.in.: pewne dobro, korzyść, przyjemność lub też coś niedobrego, niebezpiecznego, co jest jednak ważne z perspektywy funkcjonowania podmiotu. Gdzie indziej de Sousa pisze o emocjach jako „percepcjach wartości” (de Sousa, 2011, s. 37). Emocje mają swoją podstawę w biologii, ale pełnego znaczenia nabierają w kontekście odpowiednich sytuacji społecznych i kulturowych, w których podmiot uczy się rozpoznawać i przeżywać określone emocje.

Wedle de Sousy bardzo ważną sprawą jest wyznaczenie standardów dla emocji - dla poszczególnych ich typów. Standardy te filozof proponuje tworzyć, opierając się na tzw. scenariuszach paradygmatycznych. Wyznaczają one podstawowy sens (znaczenie) emocji. Wedle de Sousy scenariusze paradygmatyczne wiążą się: (1) z typem sytuacji, który umożliwia charakterystykę przedmiotów (w tym przedmiotu formalnego) danego typu emocji; oraz (2) z zestawem ,normalnych” reakcji na określoną sytuację (de Sousa, 1987, s. 181-184). Różne sytuacje i zdarzenia skorelowane są z różnymi emocjami. Gry i zabawy z radością, kłótnie i awantury - ze smutkiem.

3 W swoich analizach de Sousa uwzględnia też obliczeniowe podejście do emocji. O emocjach mówi się często, że są ostatnią, ale bardzo trudną - jeśli w ogóle możliwą - do przekroczenia barierą dla obliczeniowych teorii umysłu. Istnieją tutaj dwojakiego rodzaju obiekcje. De Sousa nazywa je obiekcjami ,góra-góra” i „dół-dół” (the top-upand, the bottom-down). Obiekcja dół-dół to taka obiekcja, w której emocje ze wszystkich naszych stanów w najbardziej prawdopodobny sposób wynikają bezpośrednio z naszej konstytucji fizjologicznej, mają zbyt wiele wspólnego z hormonami i za mało z czymkolwiek, co może zostać zaprogramowane. Obiekcja góra-góra wynika z perspektywy kontekstualizmu: emocje nie mogą być zrozumiane w kategoriach modeli obliczeniowych, ponieważ są suprasemantyczne. De Sousa wskazuje tu przede wszystkim na przedkonceptualnie subiektywne i pierwszoosobowe doświadczanie. Emocje wiążą się z naszym poczuciem siebie, z naszą istotową subiektywnością, ale też z naszymi relacjami interpersonalnymi: pragniemy być z innymi, mamy z tego radość i satysfakcję; a czasami też przeżywamy strach przed odseparowaniem i odrzuceniem społecznym (por. de Sousa, 1987, s. 70). 
Emocje nie są wrodzonymi, sztywnymi programami, ale czymś, czego nabywamy w procesie socjalizacji, czego się uczymy w określonych warunkach społeczno-kulturowych. Scenariusze paradygmatyczne tworzone są na podstawie m.in. naszych reakcji na pewne zdarzenia, ale też pod wpływem codziennych interakcji. Już w najwcześniejszym okresie życia dziecko - pozostawiając na boku kwestię emocjonalnego związku z matką - uczy się pewnych reakcji emocjonalnych poprzez naśladowanie zachowania rodziców na sytuacje oraz obserwowanie wzajemnych relacji matki i ojca. Pewne znaczenie dla rozwoju emocjonalnego mają też interakcje z rodzeństwem i rówieśnikami. W późniejszym okresie emocje kształtują się w odniesieniu do pewnych elementów życia kulturowego - opierając się na opowieściach, sztuce, literaturze.

\section{Intencjonalna struktura emocji}

Wydaje się, że zaawansowane badania nad racjonalnością emocji u de Sousy rozpoczynają się wraz z analizą intencjonalności. Przy pewnej interpretacji ludzka intencjonalność wymaga pojęć, przekonań, myślenia i języka. Właśnie tak rozumiana intencjonalność ściśle wiąże się z racjonalnością. Jeżeli teraz zgodzimy się na to, że emocje są intencjonalne, wówczas musimy również zaakceptować to, że emocje są racjonalne. Co to znaczy, że emocje są intencjonalne? W tym kontekście znaczy to, że są one nakierowane na pewien cel i mają swój specyficzny przedmiot. De Sousa nie przeczy temu, ale równocześnie pokazuje, że sprawa jest znacznie bardziej skomplikowana. Emocje bowiem nie biorą się znikąd, są czymś powodowane, a to nie jest bez znaczenia dla ich wewnętrznej treści. Od treści tej zależy również to, jak emocje ,się zachowują”, czy i jak motywują pewne działania. Wszystkie te elementy - i kilka innych - należą zdaniem de Sousy do podstawowej struktury intencjonalnej emocji. Postaram się zrekonstruować tę strukturę. Najpierw jednak kilka ogólnych uwag na temat samej intencjonalności.

Intencjonalność dla de Sousy to własność, dzięki której różne organizmy kontaktują się ze światem. Własność ta ma swoje korzenie w przyrodzie i jest stopniowalna. Zwierzęta działają, przede wszystkim kierując się intencjonalnym instynktem i potrzebami, podczas gdy człowiek działa, opierając się na pragnieniach, przekonaniach i świadomych motywach. Przykładem intencjonalności na najniższym poziomie - quasi-intencjonalności - są re- 
akcje roślin spowodowane różnymi czynnikami w środowisku, np. tropizmy (foto-, termo- czy tigmo-tropizmy). Quasi-intencjonalność charakteryzuje się (1) ,intencjonalną inegzystencją" i (2) ogólnością. Inegzystencja intencjonalna rozumiana jest przez de Sousę jako funkcjonalny odpowiednik braku przedmiotu odniesienia - to, co jest reprezentowane w stanach quasi-intencjonalnych, może w rzeczywistości nie istnieć ${ }^{4}$. Postulowana ogólność wynika z rachunku kosztów adaptacyjnych ponoszonych przez organizm. Zwierzęta, którym przysługuje quasi-intencjonalność, charakteryzują się stosunkowo niskim poziomem rozróżniania specyficznych elementów W zmiennym otoczeniu, choć jest on wystarczający do praktycznego funkcjonowania. Wyższy poziom precyzyjności w wychwytywaniu szczegółów byłby zbyt kosztowny dla organizmów i szkodliwy (por. de Sousa, 1987, s. 97).

Najbardziej rozwinięta forma intencjonalności przysługuje człowiekowi. Jest ona możliwa dzięki zasobom języka i logiki, a przejawia się w ludzkiej zdolności do odniesienia jednostkowego. Odniesienie jednostkowe charakteryzuje się tym, że podmiot posiada zdolność do tzw. indywidualnej (niezastępowalnej) identyfikacji obiektu, czyli zdolność logicznego rozróżnienia między jednostkami jakościowo nierozróżnialnymi. Kiedy człowiek ma przed sobą takie same obiekty, np. A i B, wie, że A nie jest B, a B nie jest A. Natomiast zastąpienie np. egzemplarza A egzemplarzem B czyni dla człowieka dużą różnicę. Inaczej zwierzęta. One, ze swoją skłonnością do „ogólnego odniesienia”, łatwo pomylą A z B, i odwrotnie - B z A, co nie stanowi dla nich większego problemu ${ }^{5}$. Ten najwyższy poziom intencjonalności wedle de Sousy jest warunkiem pojawienia się typowo ludzkich emocji, których obiekty są niezastępowalne (obiekty quasi-inten-

4 Jest to swobodne nawiązanie do filozofii Franciszka Brentana, wedle którego „intencjonalna inegzystencja” polega na tym, że każde zjawisko psychiczne - jako intencjonalne - odnosi się lub zawiera coś jako pewną treść lub obiekt. Istnienie pewnej treści (wewnętrznego obiektu) nie przesądza istnienia przedmiotu w świecie (do którego treść ta się odnosi). Na przykład treść pojęcia „nosorożec” ma swój przedmiot odniesienia, a pojęcie ,jednorożca" nie ma - wyobrażenie jednorogich zwierząt jest tylko wyobrażeniem (por. Brentano, 1999, s. 126).

5 Kwestia ogólnego odniesienia zwierząt, tak jak ją prezentuje de Sousa, może budzić poważne wątpliwości nie tylko etologów. Z drugiej strony nie ma wątpliwości, że człowiek jest bardziej wyrafinowany intelektualnie niż zwierzęta i przywiązuje większą wagę do detali, domaga się większej precyzji. Na temat natury zachowań poznawczo-badawczych zwierząt zob. Pisula, 2003. 
cjonalnych emocji są zastępowalne, w tym sensie, że mysz polna boi się zarówno autentycznego lisa, jak i czegoś, co tylko lisa przypomina [por. de Sousa, 1987, s. 97-100]).

Teraz przechodzę do scharakteryzowania podstawowej struktury intencjonalnej emocji, która decyduje o tym, że o emocjach można mówić w kategoriach racjonalności.

Intencjonalne emocje mają przede wszystkim cel. Celem emocji może być rzeczywisty przedmiot, zwykle realny i aktualny, na który skierowana jest emocja. Może nim być np. prezent od przyjaciela, niespodziewanie spotkany dziki pies czy porysowana karoseria nowego samochodu. Zwykle są to tego rodzaju przedmioty, ale nie zawsze. Czasami może nim być coś błędnie rozpoznanego, wspomnienie lub coś abstrakcyjnego. Toteż de Sousa przyjmuje kilka typów przedmiotów emocji. Przedmiotami emocji mogą być:

(1) Przedmiot właściwy. Jest to zawsze jakiś rzeczywisty przedmiot, w przeciwieństwie do (2) przedmiotu pozornego lub fatszywego. Przedmiot emocji może być bowiem czasami iluzoryczny. Możemy bać się lub być zazdrosnym o kogoś, kto tak naprawdę nie istnieje. Może być też błędnie rozpoznany. S może czuć gniew na sąsiada $X$, że porysował mu karoserię samochodu. S uważa, że zrobił to $\mathrm{X}$, ponieważ $\mathrm{X}$ groził mu, że tak zrobi, jeśli ten będzie parkować na chodniku. Faktycznie jednak zrobił to Y (sąsiad) i to $\mathrm{Y}$ jest właściwym przedmiotem gniewu $\mathrm{S}$.

Z przedmiotem właściwym (autentycznym) emocji mamy do czynienia wtedy, gdy podmiot posiada pełną istotną wiedzę na temat tego przedmiotu, a przedmiot ten pozostaje niezmiennie tym samym przedmiotem, bez względu na okoliczności, prowadząc do powstania emocji. Krótko mówiąc, pełni kluczową rolę w związku przyczynowym. Przedmioty te konkretyzują aspekt motywujący (o czym będzie dalej), ale też wywołują i indywidualizują poszczególne emocje, często należące do tego samego typu. Weźmy dla przykładu przeżywanie radości. Podmiot $\mathrm{S}$ w czasie t1, t2 i t3 przeżywa radość: przedmiotem radości w czasie t1 jest wiadomość o wygranej w przetargu, przedmiotem radości w czasie $\mathrm{t} 2$ jest pochwała, jaką otrzymuje $\mathrm{S}$ od przełożonego, przedmiotem radości w czasie t3 jest awans w pracy. Choć mamy tu zawsze do czynienia $\mathrm{z}$ radością $\mathrm{S}$, to poszczególne przedmioty indywidualizują tę radość.

Własność centralna i aspekt motywujacy. Z przedmiotem emocji zazwyczaj wiąże się skoncentrowanie uwagi, która jest ujęciem jakiejś 
(prawdziwej lub iluzorycznej) własności centralnej obiektu. Własność ta jest czymś, co ma duże znaczenie dla podmiotu emocji, np. własnością centralną w emocji strachu jest coś, co sprawia, że czujemy się zagrożeni, np. ostre zęby psa (w przeciwieństwie do czegoś, co jest użyteczne lub piękne), w radości - coś, co daje przyjemność (np. komplement). W pewnych warunkach własność ta jest również aspektem motywującym dla emocji. Motywacyjna rola emocji definiuje ich charakterystyczne cele. Na tym poziomie de Sousa uwzględnia też przyczynowość. Własność centralna emocji staje się jej aspektem motywującym, jeżeli stanowi jej prawdziwą przyczynę, jest aktualną własnością celu emocji oraz dostarcza zrozumiałych racjonalizacji dla jej powstania (motywacja należy do sfery racjonalnego dyskursu). Aspekty te de Sousa dokładnie analizuje na przykładach, formułując warunki emocji (por. de Sousa, 1987, s. 116-120).

W konsekwencji de Sousa wyróżnia cztery warunki emocji: (a) pierwszy warunek przyczynowy: powiązanie przyczynowe pomiędzy własnością centralną a wystąpieniem emocji jest warunkiem koniecznym, aby ta pierwsza była aspektem motywującym; oraz (b) drugi warunek przyczynowy: aby własność centralna była aspektem motywującym, musi być faktyczną własnością obiektu; (c) warunek korygowalności (corrigibility): nie istnieje niekorygowalność w dostępie do motywującego aspektu przedmiotu; podmiot ma cały czas otwartą drogę do poprawiania swoich sądów dotyczących aspektów motywujących; (d) warunek inteligibilności: aspekty motywujące muszą być racjonalnie powiązane z emocją, którą wywołują, w tym sensie, że muszą konstytuować inteligibilne racjonalizacje dla tej emocji.

(3) Przedmiot formalny. Dla każdej emocji istnieje jakość drugiego rzędu, która musi być implicytnie przypisana do aspektu motywującego, jeżeli emocja ma być inteligibilna (zrozumiała i sensowna w danych okolicznościach). Ten esencjalny element w strukturze każdej emocji jest jej przedmiotem formalnym. Jakość drugiego rzędu (np. niebezpieczeństwo) może istnieć tylko na podstawie jakości pierwszego rzędu (niebezpiecznych własności konkretnych obiektów) ${ }^{6}$. Emocje danego typu zasadniczo powinny posiadać swój własny przedmiot formalny.

6 Początkowo de Sousa uważał, że przedmiotem formalnym strachu (np. przed dzikim psem) jest coś przerażającego, potworność (fearsomeness), konstytuowana przez takie własności psa, jak „wyszczerzone ostre zęby”, „szczekanie”, ,agresywna postawa”. W późniejszych tekstach filozof Sousa utrzymywał, że przedmiotem formalnym strachu jest niebezpieczeństwo. 
O przedmiotach formalnych dowiadujemy się poprzez scenariusze paradygmatyczne, które wiążą pewne rodzaje reakcji emocjonalnych z pewnymi rodzajami sytuacji. Przedmiotem formalnym np. strachu jest niebezpieczeństwo. Najpierw mamy autentyczne i konkretne przedmioty, np. pająki, węże, wilki, niedźwiedzie, wobec których zdarzyło się człowiekowi stanąć twarzą w twarz. Ze względu na pewne własności (np. „ostre zęby”, „ostre pazury”, „dużą siłę”, „tendencję do agresji” itd.) przedmioty te okazały się niebezpieczne. Na bazie tych własności - stanowiących centralne własności strachu - konstytuują się wyższego rzędu przedmioty abstrakcyjne: niebepieczeństwo.

Ważną sprawą jest tutaj problem relacji przedmiotu rzeczywistego (lub tylko domniemanego) do przedmiotu formalnego. Wedle de Sousy przedmiot emocji, tam, gdzie istnieje, jest tym, co odgrywa decydującą rolę w wywołaniu emocji, i pojmowany jest jako coś, co konkretyzuje aspekt motywujący. Z kolei aspekt motywujący konkretyzuje obiekt formalny, który definiuje tę konkretną emocję.

(4) Przedmiot propozycjonalny. Niektóre emocje powstają w odniesieniu do istniejących i konkretnych przedmiotów, inne natomiast jedynie w odniesieniu do przedmiotów propozycjonalnych, które powstają, opierając się na języku i przekonaniach. Na przykład S ogląda film w kinie i „S jest przekonany, że X zabije Y”. Przekonanie to wywołuje niepokój czy obawę u S, który sympatyzuje z Y. Choć przedmiot propozycjonalny nie jest żadnym rzeczywistym przedmiotem, to jednak wywołuje emocje. Dzieje się tak, ponieważ przedmiot ten posiada własność tworzenia formalnego przedmiotu emocji: ,jeśli emocja posiada obiekt czysto propozycjonalny, to polega na odpowiedniej postawie wobec jakiegoś typu faktu, sądu, wydarzenia lub sytuacji, która posiada własność egzemplifikującą przedmiot formalny emocji” (de Sousa, 1987, s. 139). Wedle de Sousy należy odróżnić emocje, które generowane są przez (1) przedmiot propozycjonalny lub (2) fałszywe przekonanie o istnieniu jakiegoś przedmiotu, od tych, które wywoływane są przez tzw. (3) przedmiot hybrydowy.

W badania racjonalności emocji wpisują się rozważania de Sousy na temat natury obiektywności (T1) i prawdziwości emocji (T2) 7 .

7 Może się komuś nasunąć pytanie, które z tych pojęć - prawda, obiektywność, racjonalność - jest fundamentalne. De Sousa porównuje relacje między tymi pojęciami do gry „papier, kamień, nożyce”, w której nożyce są silniejsze od papieru, ponieważ go tną, 


\section{Obiektywność emocji}

Współczesna filozofia na wzór nauk przyrodniczych uprzywilejowała trzecioosobową i intersubiektywną perspektywę, niezależną od podmiotu (jego świadomych doświadczeń, oczekiwań, przeżyć), obiektywną rzeczywistość faktów i rzeczy. Zdaniem niektórych, w tym Roberta Solomona, ma to negatywne skutki dla życia i funkcjonowania człowieka w kulturze. Podejście takie może bowiem sugerować, że istnieje tylko jeden prawdziwy opis rzeczywistości, jedna obiektywna i wszystkich obowiązująca hierarchia wartości, jeden prawdziwy światopogląd, absolutny sens życia. Jest jednak inaczej. Dlatego Solomon programowo broni w swojej filozofii subiektywności i emocjonalności oraz surrealności (świata kreowanego przez konkretne jednostki), ale wcale ich nie absolutyzując. Nie ma bowiem obiektywności bez subiektywności. Subiektywność i obiektywność mogą - i powinny - się uzupełniać i dobrze służyć racjonalnej kulturze (por. Solomon, 1983, s. 50-65).

De Sousa - w przeciwieństwie do Solomona - broni pewnej formy obiektywności emocji. Na pytanie postawione już w Eutyfronie, czy bogowie kochają pobożność, ponieważ jest ona tym, czym jest, czyli pobożnością, czy jedynie nazywają pobożnym to, co kochają, subiektywiści udzielają negatywnej odpowiedzi - uważają, że własności ujmowane przez emocjonalny podmiot są jedynie podmiotowymi projekcjami rzeczywistości. De Sousa staje po stronie obiektywistów. A zatem, jego zdaniem, obiektywny charakter emocji oznacza, że nie są one jedynie projekcją naszych oczekiwań. Emocje są przede wszystkim obiektywne w tym sensie, że dostarczają nam rzetelnych informacji o przedmiotach i zdarzeniach w świecie. Pomagają identyfikować pewne własności w świecie i mobilizują nas do określonych postaw. Przeżycia emocjonalne, posiadające określone treści, są też doświadczeniami podmiotu i informują nas również o podmiocie. Krótko mówiąc, emocje są obiektywne, ponieważ mówią coś o podmiocie, o świecie oraz o samej relacji podmiot-świat.

kamień jest silniejszy od nożyc, ponieważ je tępi, ale papier jest silniejszy od kamienia, ponieważ go owija. Podobnie rzecz się ma z tymi pojęciami - każde ma jakąś przewagę i trudno określić, które z nich jest najbardziej podstawowe czy najważniejsze. Z pewnego punktu widzenia rywalizują ze sobą przede wszystkim obiektywność i racjonalność. Ta ostatnia wydaje się bardziej fundamentalna niż pierwsza (por. de Sousa, 1987, s. 144). 
De Sousa analizuje obiektywność w opozycji do pojęcia subiektywności, a ściśle rzecz biorąc, w opozycji do kilku różnych ujęć czy wymiarów subiektywności - w The Rationality of Emotion do czterech, a gdzie indziej do dwunastu (por. de Sousa, 2004, s. 147-164). Dziewięć z tych wymiarów odnosi się do podmiotowości, a trzy ostatnie do treści doświadczenia: (1) perspektywiczność (ujmowanie rzeczywistości z własnej perspektywy); (2) sprawstwo (wybieranie i decydowanie na podstawie własnego punktu widzenia, własne doświadczenie i własny interes); (3) przynależność (w tym sensie, że moje przeżycia przynależą do mnie w sposób konieczny i wyjątkowy, inaczej niż wtedy, gdy mówię, że jakiś przedmiot należy do mnie); (4) uprzywilejowany dostęp (moje własne przeżycia są niedostępne dla innych w taki sposób, w jaki są dostępne dla mnie samego); (5) niekorygowalność (sądy na temat moich własnych przeżyć nie podlegają żadnej formie weryfikacji, są tym, czym są dla mnie); (6) propriocepcja (głębokie odczuwanie własnego ciała, ułożenia własnego ciała w przestrzeni); (7) sobość (świadomość unikalności i niepowtarzalności własnego Ja); (8) poczucie-bycia-mną (bycie mną ma swoisty koloryt, charakterystyczny dla mnie); (9) subiektywność w intersubiektywności (konfrontacja własnych stanów z innymi); (10) projekcja (przypisywanie własnych cech lub zachowań komuś, kto ich nie posiada); (11) widzenie jako (widzenie czegoś jako czegoś - zinterpretowany ogląd); (12) doznanie fenomenalne (prywatne, subiektywne, czysto jakościowe doświadczenie czegoś, np. barwy, bólu, uczucia; na temat subiektywności zob. też: Nagel, 1986; Taylor, 1989; Searle, 1992).

Broniąc obiektywności treści emocji, de Sousa posługuje się argumentacją per analogiam. Analogia jest silna, bo zestawianymi elementami są intencjonalne stany mentalne, percepcja i emocje, które nastawione są na pewne własności realnego świata (analogia byłaby słaba, gdyby zestawiane ze sobą elementy pochodziły $z$ różnych porządków i miały wiele różnic, a mało podobieństwa). Otóż mogłoby się wydawać, że perspektywizm emocji skazuje je na subiektywność i brak obiektywności. Wszelako spostrzeganie jest również perspektywiczne: poznający podmiot w akcie percepcji zajmuje określone miejsce i czas - a zatem spostrzega pewien przedmiot z własnej perspektywy. Ponadto w polu percepcyjnym znajduje się mnóstwo danych, ale nie wszystkie są zauważane. Zwracamy uwagę na ten, a nie inny przedmiot, na te, a nie inne jego własności. To jednak nie zmienia faktu, że spostrzeganie gwarantuje nam poznanie rzeczywistości 
i sprawne w niej funkcjonowanie. „Podobnie - stwierdza de Sousa - jak zmiana perspektywy występuje z powodu zmiany otoczenia lub ruchu obserwatora, tak możemy przyjąć, że zmiany emocji odzwierciedlają zmiany naszej relacji do obiektywnego celu emocji" (de Sousa, 1987, s. 225). Emocje, podobnie jak percepcja, nakierowane są na obiektywną rzeczywistość, na pewne własności świata. Wspierają poznanie rzeczywistości i sprawne w niej funkcjonowanie.

Można próbować podważać obiektywność emocji na różne sposoby. Niektórzy identyfikują emocje, opierając się na ich doznaniowo-fenomenalnym charakterze - emocjom towarzyszy subiektywne odczucie. To jednak, zdaniem de Sousy, nie podważa wartości analogii emocji z percepcją. Percepcje bowiem również zawierają w sobie jakości fenomenalne (to jest właśnie ta ich subiektywna strona). Fenomenalna jakość emocji mówi o tym, jak obiektywna własność jawi się podmiotowi z jego własnej perspektywy (de Sousa, 1987, s. 149-150).

Percepcja zachodzi wtedy, gdy podmiot odbiera określone bodźce. Może zachodzić poprawnie lub niepoprawnie. W sytuacji drugiej możliwe są dwojakiego rodzaju zaburzenia: halucynacje i iluzje. Z pierwszymi mamy do czynienia wtedy, gdy podmiot widzi, słyszy lub odczuwa coś, czego tak naprawdę nie ma. Natomiast iluzje jedynie zniekształcają odbiór istniejących obiektów. Możliwe są też emocjonalne halucynacje i iluzje. W przypadku emocjonalnej halucynacji nie istnieje cel emocji, natomiast w przypadku emocjonalnej iluzji złudna jest własność centralna emocji. Tak jak można odróżnić poprawne percepcje od zaburzonych, tak można też odróżnić poprawne emocje od iluzorycznych i poprawne emocje od emocjonalnych halucynacji.

W tym kontekście nasuwa się jednak pytanie o to, czy i w jaki sposób emocje odnoszą się do rzeczywistości, jak ją oceniają, czy - innymi słowy - można im przypisać wartość prawdziwości.

\section{Prawdziwość emocji}

Z rozważań zawartych w The Rationality of Emotion wyłania się przynajmniej kilka możliwych ujęć problemu prawdziwości emocji. Oto jedno z nich: emocja prawdziwa to emocja autentyczna, rzeczywiście przeżywana przez podmiot, odsłaniająca prawdziwą naturę jego życia wewnętrznego. 
Inne rozwiązania wyłaniają się z opisanej wcześniej struktury intencjonalnej emocji. Jak pamiętamy, pewna emocja może być nakierowana na jakiś konkretny przedmiot czy zdarzenie, na przedmiot formalny lub na przedmiot propozycjonalny. W tym kontekście prawdziwość emocji może być rozumiana jako pewna forma zgodności lub spójności. I w tym duchu problem prawdziwości emocji próbuje rozwiązać de Sousa.

Zagadnienie to de Sousa analizuje w Emotional Truth w nawiązaniu do korespondencyjnej teorii prawdy - opierając się na słabym rozumieniu korespondencji. De Sousa utrzymuje, że nośnikami prawdy są stany mentalne (a nie zdania, sądy lub stwierdzenia, jak uważają zwolennicy propozycjonalnego ujęcia). Zgodnie z bronioną przez siebie koncepcją prawdy rodzajowej (generic truth) filozof przyjmuje, że o stanie mentalnym M można orzec, że jest prawdziwy (lub fałszywy), wtedy i tylko wtedy, gdy:

(1) M podlega normie $\mathrm{N}$;

(2) $\mathrm{N}$ jest określona przez sam $\mathrm{M}$, ale

(3) dla swojego spełnienia N potrzebuje jakiejś rzeczywistości istniejącej niezależnie od M (de Sousa, 2011, s. 55).

Ta koncepcja prawdy dotyczy przekonań i emocji, ale natura jednych i drugich jest inna i w związku z tym natrafiamy tutaj na komplikacje o charakterze logicznym. Pewne przekonanie może być zanegowane w wyniku przeciwieństwa lub sprzeczności. Przekonania wymagają niesprzeczności: jeżeli $p$ i $q$ są sprzeczne, to sprzeczność owa jest automatycznie wskazaniem, że przekonanie, że $p$, i przekonanie, że $q$ nie mogą być równocześnie prawdziwe. Czy dotyczy to również emocji? Nie do końca, bo w emocje wpisane jest pojęcie przeciwieństwa. Otóż wiele emocji można opisać w dwóch opozycyjnych wymiarach (często mówi się o dodatnim i ujemnym znaku emocji): miłość i nienawiść, radość i smutek, nadzieja i rozpacz, podziw i pogarda. Takie pary niewątpliwie należy rozpatrywać w kategoriach przeciwieństw. W związku z tym emocje, ale też i pragnienia, nie wymagają takiej niesprzeczności, jakiej wymagają przekonania. Najlepiej widać to w przypadku pragnień: dwa pragnienia mogą dążyć do dwóch sprzecznych stanów rzeczy bez pociągania za sobą wniosku, że jeden z nich jest błędny. Wedle de Sousy nie należy zakładać jednego kryterium niesprzeczności dla przekonań, pragnień i emocji. Należy odróżnić i nie mieszać warunków spetnienia pragnienia $\mathrm{z}$ warunkami sukcesu.

Dla jakichkolwiek dwóch przekonań zgodność pokrywa się z niesprzecznością. Jednak by dwa pragnienia były niesprzeczne, nie jest koniecz- 
ne to, by ich treści były wspólnie spełnialne, ale tylko żeby ich treści były wspólnie pożądane. Tak więc, mimo że pragnienie $p$ i pragnienie $q$ (gdzie $q$ implikuje $\sim p$ ) są wyraźnie niezgodne, to nie wynika z tego, że powinny być uznawane za sprzeczne. Sprzeczne pragnienia mogą być ,pragnieniami zgodnych przedmiotów".

Biorąc za podstawę rozróżnienie na warunki spełnienia i sukcesu (skuteczności, fortunności), de Sousa przyjmuje, że pewien stan emocjonalny jest spełniony, jeżeli zachodzi w świecie coś, co ten stan wywołuje. Natomiast pewien stan emocjonalny jest skuteczny, jeśli wydarzenie będące przedmiotem naszej emocji poprawnie odpowiada jego przedmiotowi formalnemu. Bogaty świat emocji zakłada, że emocje mogą mieć różny przedmiot.

Zgodnie z definicjami de Sousy:

(1) Dla emocji z przedmiotem propozycjonalnym $(p)$ :

$\mathrm{E}(p)$ jest spetniona wtedy i tylko wtedy, gdy $p$ jest prawdziwe; oraz

$\mathrm{E}(p)$ jest udana, jeśli $p$ jest faktycznie dopasowane do przedmiotu formalnego E (de Sousa, 2011, s. 57).

(2) Dla emocji z celem $(t)$ :

$\mathrm{E}(t)$ jest spetniona wtedy i tylko wtedy, gdy $t$ istnieje; oraz

E $(t)$ jest udana, jeśli $t$ jest faktycznie dopasowane do przedmiotu formalnego E (de Sousa, 2011, s. 58).

Ogólnie rzecz biorąc, jak widać, emocja jest prawdziwa wtedy i tylko wtedy, gdy jej rzeczywisty przedmiot pasuje do przedmiotu formalnego.

Tam, gdzie emocja posiada przedmiot propozycjonalny, spełnienie opiera się na prawdzie, a sukces na dopasowaniu do przedmiotu formalnego. Tam, gdzie emocja dopuszcza cel $(t)$, ale gdzie brakuje jej przedmiotu propozycjonalnego (jak w wypadku pewnych form strachu), semantyczne spełnienie polega na udanej referencji, podczas gdy sukces wciąż zależy od tego, czy cel pasuje do przedmiotu formalnego dla emocji z rzeczywistym celem.

Szeroka koncepcja prawdy jako sukcesu nie wyklucza tego, że pewne stany intencjonalne mają treści propozycjonalne (zdania, sądy, stwierdzenia) i są prawdziwe bądź fałszywe w sensie wąskim. Wszystkie jednak - skuteczne bądź nieskuteczne - są prawdziwe bądź fałszywe w sensie szerokim.

Na koniec dodajmy, że choć dla prawdziwości emocji kluczowe jest dopasowanie do przedmiotu formalnego, to jednak de Sousa brał też pod uwagę inny standard dopasowania, a mianowicie szeroką refleksyjną równowagę faktów biologicznych, norm społecznych i indywidualnego 
doświadczenia. Niestety, filozof tego wątku nie rozwija i - jak zauważa Mikko Salmela - nigdzie nie daje przykładu takiej równowagi ${ }^{8}$.

Pogląd, że emocje mają charakter obiektywny oraz że emocjom - przynajmniej niektórym - można przypisać prawdziwość, pociąga za sobą tezę, że emocje mogą być racjonalne.

\section{Racjonalność emocji}

W The Rationality of Emotion de Sousa wyróżnia trzy rodzaje racjonalności: (1) poznawczą; (2) strategiczną oraz (3) aksjologiczną. Każda z nich ma swoją dynamikę i swoje cele. W (3) de Sousa przypisuje emocjom standardy racjonalności, które są nieredukowalne do standardów racjonalności typu (1) i (2).

Racjonalność poznawcza i strategiczna. Racjonalność poznawcza opiera się na ciekawości, przekonaniach i sądach. Dodajmy: przekonaniach i sądach wiarygodnych. Wiarygodne przekonania i sądy to takie, które powstały na bazie wiarygodnych reguł poznawczych. Celem racjonalności poznawczej jest poznanie prawdy. Natomiast racjonalność strategiczna opiera się na pragnieniach i działaniu. Należy ją rozpatrywać w kategoriach korzyści, jakie może osiągnąć podmiot. Podmiot działa racjonalnie (strategicznie), gdy (1) działa celowo; (2) celem tym jest jakieś dobro - korzyści dla podmiotu (w rezultacie zawsze jest to jakiś stan rzeczy); (3) do których dobiera odpowiednie strategie. „Różnica między racjonalnością strategiczną i poznawczą może być postrzegana jako kwestia kierunku dopasowania: cele poznawcze dopasowują umysł do świata, podczas gdy cele strategiczne dopasowują świat do umysłu" (de Sousa, 1987, s. 163).

Każda z tych racjonalności posiada swoje własne antynomie. Czasami też standardy racjonalności poznawczej mogą wchodzić w konflikt ze

8 Wedle Salmeli ,prawda emocjonalna” de Sousy ma dwie główne słabości. Po pierwsze, sama idea prawdy jako sukcesu jest chybiona - prawda emocji nie może zostać zdefiniowana w kategoriach tylko samego jej sukcesu. Wiązałoby się to bowiem z tym, że mój strach przed potworami jest prawdziwy o tyle, o ile potwory są niebezpieczne, bez względu na to, czy one istnieją, czy nie. Po drugie, jest to koncepcja zbyt ogólnikowa i mglista. Idea szerokiej refleksyjnej równowagi faktów biologicznych, norm społecznych $\mathrm{i}$ indywidualnego doświadczenia jako standard dopasowania pozostaje nazbyt pobieżna (por. Salmela, 2014, s. 107-108; zob. też Krzemkowska-Saja, 2013, s. 47-61). 
standardami racjonalności strategicznej, np. kiedy obrona prawdziwego przekonania skutkuje niekorzystnymi konsekwencjami dla praktyki życia lub odwrotnie, kiedy podtrzymywanie jakiegoś błędnego przekonania prowadzi do korzystnych dla podmiotu konsekwencji. Której racjonalności wówczas podmiot powinien słuchać? Co uznać za ważniejsze: prawdziwość przekonań czy własną korzyść? Dylemat ten de Sousa obrazuje zakładem Pascala. Francuski filozof przekonuje, że nawet jeśli nie jesteśmy przekonani, że Bóg istnieje, to zwyczajnie opłaca się nam - rezygnując ze standardów racjonalności poznawczej - wierzyć w jego istnienie, albowiem jeśli opowiemy się za istnieniem Boga wbrew własnemu przekonaniu i w przyszłości okaże się, że On istnieje, wówczas osiągniemy szczęśliwe życie wieczne (por. de Sousa, 1987, s. 164, 2011, s. 7-8). Przykład nie jest najlepszy, bo po pierwsze, pozostawia wszystko w sferze możliwości, a po drugie, jeśli okaże się, że Bóg i życie wieczne istnieją, to wówczas nasze przekonanie o nieistnieniu Boga zostanie zweryfikowane i okaże się fałszywe, a nie prawdziwe.

Wedle de Sousy emocje mają duże znaczenie dla racjonalności naszych przekonań i działań. Przede wszystkim kierują naszą uwagę na to, co ważne dla nas, pozwalając ocenić ważność informacji. Umożliwiają szybką decyzję i gwarantują korzystne wybory - analiza logiczna racji za i przeciw pewnej opcji jest niewystarczająca do skutecznego działania, w pewnych sytuacjach zajmuje zbyt wiele czasu i wymaga zbyt wielu środków. Jak wiadomo z teorii decyzji, liczba możliwych logicznie celów do realizacji w różnych sytuacjach jest olbrzymia, podobnie jak liczba możliwych strategii, które mogą być wykorzystane do ich osiągnięcia. Ponadto należy przewidywać konsekwencje różnych opcji. Rozważając możliwe strategie, liczba konsekwencji każdej z nich wydaje się nieskończona9 ${ }^{9}$ Jak w takich warunkach działać? Rozwiązaniem tego problemu są właśnie emocje. Bez wsparcia ze strony emocji $\mathrm{w}$ pewnych sytuacjach moglibyśmy rozważać potencjalne opcje przez całe życie i nigdy się na żadną z nich nie zdecydować.

Racjonalność aksjologiczna. Racjonalność aksjologiczna jest racjonalnością emocji. Celem racjonalności poznawczej była prawda, strategicznej

9 Wiąże się to z tzw. problemem ramy (frame problem). Ludzie w swoich wyborach nie uwzględniają wszystkich możliwych informacji, w punkcie wyjścia wiele możliwości eliminują, nie tracą czasu na badanie, czy pewne dane są istotne, czy nie. Tego nie potrafią robić komputery. 
- dobro lub korzyść. Celem racjonalności aksjologicznej jest jakaś wartość: to, co ważne dla życia podmiotu. Wedle de Sousy emocje są racjonalne, jeśli wydają obiektywne wyroki w sprawie tychże wartości. A czynią tak, jeśli spełniają kilka warunków.

W punkcie wyjścia de Sousa wyróżnia i analizuje sześć generalnych zasad racjonalności w ogóle. Zasady te, zgodnie z intencją autora, nie dają wyczerpującej charakterystyki, lecz jedynie wyznaczają ogóle ramy dla zrozumienia omawianej dalej racjonalności emocji (por. de Sousa, 1987, s. 158-165). Są to:

R1: Sukces (odpowiednie dopasowanie). Formalny przedmiot pewnego intencjonalnego stanu określa kryterium sukcesu tego stanu, w kategoriach którego może zostać oceniona racjonalność tego stanu. Sukcesem jest odpowiednie dopasowanie stanu intencjonalnego do jego przedmiotu formalnego: „definiuję sukces jako osiągnięcie przez stan intencjonalny jego przedmiotu formalnego" (de Sousa, 1987, s. 158). A zatem kryterium sukcesu, np. strachu, jest jego przedmiot formalny - „niebezpieczeństwo”.

R2: Minimalna racjonalność. Jest to racjonalność kategoryczna, podstawowa i opisowa (nienormatywna). Niezbędnym warunkiem stanu intencjonalnego - kategorycznie racjonalnego - jest to, że zgodnie z pewnym prawdziwym opisem może być poprawnie określony jako ewaluacyjnie racjonalny (albo irracjonalny).

R3: Intencjonalność. Teleologia zawarta $\mathrm{w}$ racjonalności odnosi się tylko do intencjonalnych stanów lub działań.

R4: Źródta (Origins) Ocena racjonalności każdego stanu uwzględnia przede wszystkim genezę i możliwe konsekwencje: „Ocena racjonalności działania lub przekonania patrzy zarówno na konsekwencje, logiczne i przyczynowe, jak i na genezę" (de Sousa, 1987, s. 159).

R5: Ograniczenia. Racjonalność nigdy niczego nie nakazuje, ale jedynie ogranicza poprzez piętnowanie niespójności i jałowych rozróżnień.

R6: Poznawcza i strategiczna racjonalność. Stan reprezentacyjny może być oceniony pod względem wartości jego prawdopodobnych efektów, co określa jego strategiczną racjonalność lub użyteczność. Stan jest natomiast poznawczo racjonalny, jeżeli adekwatnie odnosi się do jakiegoś stanu rzeczy w świecie (gdy jest prawdziwy).

Następnie de Sousa przechodzi do zbadania zastosowania tych zasad do emocji. Jego zdaniem zasady R1-R5 stosują się do racjonalności emocjonalnej. Natomiast zasada R6 odzwierciedla rozróżnienie pomiędzy 
poznawczą a strategiczną racjonalnością (zasadniczo polega ono na kierunku dopasowania: racjonalność poznawcza przyjmuje kierunek umysł-świat, a strategiczna: świat-umysł).

Wynika stąd, że pewna emocja jest racjonalna, jeżeli: (1) osiąga swój przedmiot formalny; (2) spełnia warunek minimalnej racjonalności; (3) jest stanem intencjonalnym; (4) uwzględnia przyczyny i konsekwencje oraz zachowuje (5) spójność.

Jeżeli emocja poprawnie dopasowuje się do swoich przedmiotów formalnych, to jest zrozumiała (przedmioty formalne bowiem określają warunki poprawności emocji). Przekonania mają jeden przedmiot formalny, jest nim prawda. Natomiast nie istnieje jeden przedmiot formalny dla wszystkich emocji. Każdy typ emocji ma swój własny przedmiot formalny, który superweniuje na naturalnych własnościach przedmiotu czy zdarzenia. Poza tym, co z tego wynika, emocja jest minimalnie racjonalna. Jest tak, jeżeli emocja jest reakcją na sytuację, która przypomina paradygmatyczny scenariusz tej emocji i w ten sposób osiąga swój cel. Ponadto istotne jest tu odwołanie do przyczyn. Szczególnie ważne jest chyba odwołanie do przyczynowości sprawczej, ona bowiem wyznacza odpowiedni przedmiot formalny. I wreszcie zasada unikania niespójności i jałowych rozróżnień. Otóż, podkreślmy, postulat spójności (koherencji) jest minimalnym warunkiem każdego typu racjonalności. „Dwa przekonania, którym odpowiadają sądy sprzeczne, nie mogą istnieć zarazem w tym samym umyśle" (Łukasiewicz, 1987, s. 12-13). W obliczu wykrycia sprzeczności we własnym umyśle podmiot dąży do wyjaśnienia jej źródeł i - ewentualnie - do wyeliminowania przekonania, które narusza spójność systemu przekonań. Jednak standardy niesprzeczności przekonań różnią się od standardów spójności emocji (i pragnień). Po odróżnieniu „spójności” od „zgodności”, o czym była już mowa wcześniej, de Sousa przyjmuje, że racjonalne współistnienie poszczególnych emocji jest kwestią ich spójności, a nie zgodności. Zgodność emocji opiera się na możliwości jednoczesnego ich spełnienia, natomiast spójność emocji opiera się na ich skuteczności. Pewne dwie emocje są niespójne, gdy ich przedmioty formalne są ze sobą sprzeczne. 


\section{Zakończenie}

W artykule skoncentrowałem się na najważniejszych elementach filozofii emocji de Sousy, która wyrosła z silnego przekonania, że emocje były lekceważone i zaniedbywane w refleksji filozoficznej - wciąż potrzebują wielostronnych i pogłębionych badań.

Studiowanie prac de Sousy nie jest łatwe przynajmniej z dwóch powodów. Po pierwsze, ze względu na pewien typ liberalnej interdyscyplinarności. W swoich analizach, wyjaśnieniach i interpretacjach tego, czym są i jak powstały emocje, de Sousa nawiązuje do różnych dyscyplin i korzysta $z$ wielu pozytywnych ustaleń różnych nauk: przyrodniczych, społecznych i humanistycznych. Konsekwentnie korzysta też z różnych sposobów i strategii wyjaśniających, do których należą m.in.: wyjaśnienia przyczynowe, teleologiczne i intencjonalne. Po drugie, badanie prac de Sousy jest trudne ze względu na zawiły styl tego filozofa. Czasami pisze on ogólnie i metaforycznie, innym razem precyzyjnie, aż nazbyt technicznie. Często wyjaśnia ,trudne przez trudniejsze”. Argumentacja de Sousy jest złożona, wielostopniowa i nie zawsze oczywista (oprócz tych miejsc, gdzie autor argumentuje bezpośrednio i wyraźnie). Nie wszystko jest jasne i przekonywające w pracach de Sousy. Pora jednak skoncentrować się na mocnych stronach tej filozofii.

Po pierwsze, pomysł, że emocje wiążą się z ważnymi wydarzeniami dla (funkcjonowania) podmiotu czy, mówiąc nieco dokładniej, że są quasi-percepcjami wartości, jest dobrym punktem wyjścia w analizie natury emocji (w świetle słabości silnych teorii poznawczych). Jest to punkt wyjścia de Sousy. Ale tylko punkt wyjścia. Ponadto filozof stara się uwzględnić wszystkie ważne kwestie dla emocji i optuje za stworzeniem koncepcji integralnej. Wielu teoretyków próbuje redukować zjawiska afektywne do prostszych elementów: albo do zmian fizjologiczno-cielesnych, albo do przekonań lub pragnień i przekonań, albo do motywacji, albo konstrukcji społecznych. De Sousa postrzega emocje jako złożone zjawiska, dla których tożsamości wszystkie te aspekty są ważne.

Po drugie, trzeba docenić wysiłek de Sousy w kwestii wyjaśnienia intencjonalności emocji. Wielu filozofów tylko zakładało, że emocje są intencjonalne, albo ograniczało się do ogólnych uwag. Mało kto - może z wyjątkiem Maxa Schelera - tak gruntownie przebadał ten problem. De Sousa m.in. odwołując się do celu, przedmiotu rzeczywistego lub iluzorycz- 
nego oraz przedmiotu formalnego i/lub propozycjonalnego zrekonstruował strukturę intencjonalną emocji. Można mieć oczywiście wątpliwości, czy wszystkie wyodrębnione przez niego elementy struktury intencjonalnej są niezbędne do opisania każdej emocji. Tutaj natrafiamy na fundamentalną trudność, a mianowicie na problem złożoności zjawisk afektywnych. Kluczową sprawą pozostaje wciąż kwestia posegregowania emocji i zbudowania odpowiednich klasyfikacji.

Po trzecie, na uwagę zasługuje przyjęcie obiektywistycznej perspektywy w kwestii emocji (wbrew subiektywistom). Dla wielu pomysł, że nasze emocje mają charakter obiektywny, wydawać się może wysoce kontrowersyjny. Zwłaszcza dla tych, dla których emocje są czymś, co jest zlokalizowane wyłącznie wewnątrz podmiotu. Emocje niewątpliwie mają swoją stronę subiektywną. Nie wyczerpuje ona jednak całej prawdy o nich. Są one strukturami znacznie bardziej złożonymi. Są też obiektywne, ponieważ tworzą trwały element struktury psychofizycznej podmiotu oraz dlatego, że dostarczają nam informacji na temat świata. Emocje ujmują rzeczy takimi, jakimi one są, i dostarczają nam ważnych informacji na ich temat, np., że pewne rzeczy są niebezpieczne, naganne, nieuczciwe, dziwne, absurdalne, niepokojące, a inne w jakiś sposób wartościowe, dobre, pożyteczne, przyjemne lub piękne. Ale o obiektywności emocji możemy też mówić wówczas, gdy mamy do czynienia z normalnie funkcjonującym podmiotem, który w podobnych okolicznościach przeżywa podobne emocje (przynajmniej, gdy mowa o emocjach podstawowych). Wreszcie obiektywność może ktoś przypisywać emocjom $\mathrm{z}$ tego powodu, że pojawiają się one niezależnie od woli podmiotu.

W zagadnienie to wpisane są dwie inne ważne sprawy, a mianowicie kwestia poznawczego charakteru emocji i zagadnienie prawdy. Na pewno warto zajmować się rolą poznawczą emocji i kwestią ich obiektywności, ale nie jestem przekonany - nie przekonał mnie do tego również de Sousa - czy relacje między emocjami i światem należy opisywać w kategoriach prawdy. Emocje nie są po to, by wyrażać prawdę, choć na pewno mogą być odpowiednie, właściwe lub poprawne. Na temat emocji można oczywiście głosić prawdę lub fałsz. Na przykład sąd stwierdzający przeżycie pewnej emocji - powiedzmy strachu - u S może być prawdziwy, jeśli tylko emocja ta pojawiła się u niego w określonym czasie, gdyż prawdziwe jest tylko to, co zachodzi, co istnieje. Są to jednak różne sprawy i całkiem inne poziomy. 
Po czwarte, uznać trzeba poważny wkład de Sousy w rozumienie problemu racjonalności emocji. $\mathrm{Z}$ przeprowadzonych przez niego analiz wynika, iż antagonistyczne ustawianie emocji wobec rozumu, traktowanie ich jako irracjonalnych (lub nieracjonalnych) jest poważnym uproszczeniem i w świetle wielu współczesnych badań jest już nie do utrzymania. W wielu sytuacjach emocje sprzyjają racjonalnemu myśleniu i racjonalnemu działaniu, wspierają optymalne funkcjonowanie osoby. Co więcej, de Sousa pokazał, w jakim sensie same emocje mogą być racjonalne wedle własnych kryteriów. To nie zmienia faktu, że w niektórych sytuacjach emocje mogą także prowadzić na bezdroża. Same z siebie nie są też w stanie ocenić np. celu działania pewnego podmiotu (choć pomagają go wyznaczyć) i ostatecznie - jak się wydaje - zawsze powinny współpracować z rozumem.

$\mathrm{Na}$ koniec wypada podkreślić ogromne bogactwo pomysłów, jakie znajdujemy w twórczości de Sousy. Interesujących i inspirujących pytań i sugestii jest chyba więcej niż pozytywnych rozwiązań i jasno wyłożonych propozycji teoretycznych. Filozoficzna twórczość de Sousy jest tak bogata i ekspresywna, jak samo życie emocjonalne człowieka.

\section{Bibliografia}

Ben-Ze'ev, A. (2000). The Subtlety of emotions. Cambridge: MIT Press.

Brady, M.S. (2013). Emotional Insight. The Epistemic Role of Emotional Experience. Oxford: Oxford University Press.

Brentano, F. (1999). Psychologia z empirycznego punktu widzenia. Warszawa: Wydawnictwo Naukowe PWN.

Brun G., Doğuoğlu U., Kuenzle D., (eds.). (2008). Epistemology and Emotions. Hampshire: Ashgate.

Elgin, C.Z. (2008). Emotion and Understanding. W: G. Brun, U. Doğuoğlu, D. Kuenzle, (eds.), Epistemology and Emotions (s. 33-49). Hampshire: Ashgate.

Elster, J. (1999). Alchemies of the Mind: Rationality and the Emotions. New York: Cambridge University Press.

Elster, J. (2009). Reason and Rationality. Princeton-New York: Princeton University Press.

Elster, J. (2009). Emotions. W: P. Hedström, P. Bearman, (eds.), The Oxford Handbook of Analytical Sociology (s. 51-71). Oxford: Oxford University Press. 
Elster, J. (2010). Emotional Choice and Rational Choice. W: P. Goldie, (eds.), The Oxford Handbook of Philosophy of Emotions (s. 263-282). Oxford: Oxford University Press.

Goldie, P. (ed.). (2010). The Oxford Handbook of Philosophy of Emotions. Oxford: Oxford University Press.

Goldie, P. (2000). The Emotions. A Philosophical Exploration. Oxford: Clarendon Press.

Griffiths, P.E. (1997). What Emotions Really are: The Problem of Psychological Categories. Chicago: University of Chicago Press.

Hedström, P., Bearman, P., (eds.). (2009). The Oxford Handbook of Analytical Sociology. Oxford: Oxford University Press.

Helm, B.W. (2007). Emotional Reason: Deliberation, Motivation, and the Nature of Value. Cambridge: Cambridge University Press.

James, W. (2002). Psychologia. Kurs skrócony. Warszawa: Wydawnictwo Naukowe PWN.

Krzemkowska-Saja, J. (2014). Ontologia i epistemologia emocji w ujęciu Ronalda De Sousy. Analiza krytyczna. Uniwersytet Szczeciński [doktorat].

Krzemkowska-Saja, J. (2013). Czy potrzebujemy pojęcia prawdy emocjonalnej?, Przeglad Filozoficzny, 1 (85), 47-61.

Larrazabal, J.M., Pérez Miranda, L.A. (eds.). (2004). Language, Knowledge, and Representation. Dordrecht: Kluwer Academic Publisher.

Levi-Strauss, C. (2001). Myśl nieoswojona. Warszawa: KR.

Łukasiewicz, J. (1987). O zasadzie sprzeczności u Arystotelesa. Warszawa: PWN.

Marks, J. (1982). A Theory of Emotion. Philosophical Studies: An International Journal for Philosophy in the Analytic Tradition, 42 (2), 227-242.

Marks, J., Ames, R.T. (eds.). (1995). Emotions in Asian Thought. A Dialogue in Comparative Philosophy. Albany: State University of New York Press.

Nagel, T. (1986). The View from Nowhere. Oxford: Oxford University Press.

Pisula, W. (2003). Psychologia zachowań eksploracyjnych zwierząt. Gdańsk: GWP.

Prinz, J.J. (2004). Gut Reactions: a Perceptual Theory of Emotion. New York: Oxford University Press. 
Rorty, A.O. (ed.). (1980). Explaining Emotions, Berkeley: University of California Press.

Salmela, M. (2014). True Emotions. Amstrdam/Filadelfia: John Benjamins Publishing Company.

Searle, J.R. (1983). Intentionality: An Essay in the Philosophy of Mind. New York: Cambridge University Press.

Searle, J.R. (1992). The Rediscovery of the Mind. Cambridge, MA: MIT Press.

Solomon, R. (1983). The Passions. The Myth and Nature of Human Emotion. Notre Dame, Indiana: University of Notre Dame Press.

Sousa, R. de (1980). The Rationality of Emotions. W: A.O. Rorty (ed.), Explaining Emotions (s. 127-151). Berkeley: University of California Press.

Sousa, R. de (1987). The Rationality of Emotion. Cambridge, MA - London: The MIT Press.

Sousa, R. de (2011). Emotional Truth. New York: Oxford University Press.

Sousa, R. de (2008). Logic and Biology: Emotional Inference and Emotions in Reasoning. W: J.E. Adler, L.J. Rips (eds.), Reasoning Studies of Human Inference and its Foundations (s. 1002-1015). Cambridge: Cambridge University Press.

Sousa, R. de (2004). Twelve Varieties of Subjectivity: Dividing in Hopes of Conquest. W: J.M. Larrazabal, L.A. Pérez Miranda (eds.). Language, Knowledge, and Representation (s. 147-164). Dordrecht: Kluwer Academic Publisher.

Sousa, R. de (2010). The Mind Bermuda Triangle: Philosophy of Emotions and Empirical Science. W: P. Goldie (ed.), The Oxford Handbook of Philosophy of Emotions (s. 95-117). Oxford: Oxford University Press.

Taylor, C. (1989). Sources of the Self. Cambridge, MA: Harvard University Press.

\section{CAN EMOTIONS BE RATIONAL? \\ THE ANALYSIS OF SOME ASPECTS OF RONALD DE SOUSA'S PHILOSOPHY OF EMOTION}

\section{Summary}

In the paper I examine the three aspects of Ronald de Sousa's philosophy of emotions: intentionality, objectivity, and rationality of emotions. In the beginning, I put up the basic question, how he sees emotions? De Sousa argues that emotions are 
a kind of perception (perception of axiological properties). At the same time he defends an objectivist approach to emotions. It implies that emotion apprehends something in the world that exists independently of us. The fundamental question, how emotions relate to their objects, leads to the inquiry on the intentional structure of emotion and, then, to the study of the truth of emotion. Finally, I reconstruct a very important study concerning rationality: cognitive rationality, strategic rationality, and axiological rationality. The latter one is specific to the emotions. 